\title{
Ressenya de Porroche-Escudero, Coll-Planas i Riba (Eds.) (2016): Cicatrius (in)visibles. Perspectives feministes sobre el càncer de mama
}

Keren Manzano González

Universitat de Vic - Universitat Central de Catalunya

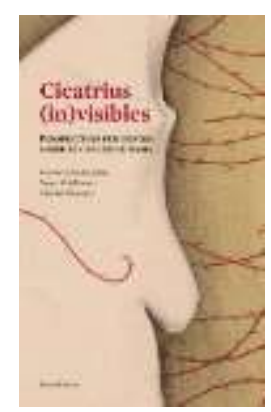

No hi ha una única radiografia que pugui explicar aquesta dolència. El càncer de mama és una malaltia complexa en la qual s'intersequen múltiples factors que no apareixen als discursos hegemònics. Sovint, aquesta malaltia no és una lluita per la supervivència, ni un esforç de superació que es recompensa amb el restabliment de la salut. Sovint, no té la cara d'una dona blanca, heterosexual o de classe mitjana. Sovint queda amagada rere estampes positives i llacets roses. ¿Què succeeix amb les històries que no es veuen?

Un equip multidisciplinar coordinat per Ana Porroche-Escudero, Gerard Coll-Planas i Caterina Riba revela factors ignorats del càncer $i$ s'aproximen als múltiples angles d'aquesta dolència. El resultat d'aquesta exploració és $\mathrm{C} i$ catrius (in)visibles, una compilació d'articles escrits per investigadores, professionals de la
Porroche-Escudero, Ana;

Coll-Planas, Gerard \& Riba Caterina (Eds.) (2016). Cicatrius (in)visibles. Perspectives feministes sobre el càncer de mama. Barcelona: Eumo Editorial.

ISBN: 978-84-9766-564-3 medicina, acadèmiques especialitzades i dones que han travessat l'experiència el càncer de mama, i que aborden la malaltia des de la perspectiva de gènere. Els textos s'organitzen en tres apartats als quals s'exploren diverses cares del prisma.

El primer, posa el focus en la construcció social del càncer de mama. Mostra com les ideologies dominants signifiquen la malaltia i com aquests significats culturals es concreten en pràctiques socials i experiències personals de les afectades. Una de les ideologies que impregnen els discursos del càncer és la del pensament positiu que individualitza el problema i el despolititza:

"[El pensament positiu] no reconeix els límits de la nostra capacitat d'intervenció, perquè individualitza l'atribució de responsabilitats invi- 
sibilitzant els factors socials, biològics o tecnològics que incideixen en les nostres vides" (Coll-Planas, 2016, p. 41).

El recurs de l'apoderament és altre procés d'individualització del càncer. Les autores analitzen la doble cara de l'apoderament a les campanyes de sensibilització. El que pretén ser una contribució a l'enfortiment de les dones, escampa/assenta la por, individualitza el problema, i atribueix exclusivament a les dones la responsabilitat de curar-se. Les culpabilitza si no prenen el paper que s'espera d'elles. Aquest és, el rol de la bona pacient que és dòcil i disciplinada.

Les autores de Cicatrius (in)visibles fan aflorar noves possibilitats de viure la malaltia, fora dels rols tradicionals de la feminitat. Reconeixen l'autonomia de les dones per prendre decisions sobre la seva pròpia salut. Demanden informació veraç perquè les dones puguin escollir com travessar la seva experiència amb coneixement de causa. Proposen, també, noves formes de pensar el cos i la sexualitat de les dones. El pit és, expliquen, una part del cos amb gran significació social. Es constitueix com un símbol de feminitat del qual preval la seva funció ornamental, front a la seva funció sensorial i com a font de plaer per les dones. Després de ser devastat pel càncer, les institucions mèdiques restauren el cos de les afectades adaptant-lo a la sexualitat, al plaer $\mathrm{i}$ al desig masculins. Només així la dona queda restituiida i la seva feminitat intacta.

L'enfocament androcèntric dels discursos institucionals del càncer impacta, de manera particular, sobre les dones en funció de la seva sexualitat, la seva classe social i la raça. La mirada interseccional que apliquen les autores sobre els processos mèdics del càncer evidencia la necessitat de reconèixer les desigualtats socials i els processos de discriminació que es configuren com a determinants socials del càncer. El text posa llum sobre les experiències del càncer als marges de la sexualitat -es recullen vivències de dones queer, lesbianes, bisexuals i trans-, i constata com les informacions $i$ el tractament que reben les pacients, sovint reifica els estereotips que existeixen al voltant d'aquestes dones.

El segon apartat explora els biaixos androcèntrics, econòmics i polítics en la biomedicina. Les institucions sanitàries tracen un camí que les afectades han de transitar si volen obtenir la seva cura. Un camí abonat amb expectatives de gènere. Com si restaurar la feminitat de les dones, després de la malaltia, fos una part del procés per tenir salut. Les autores indaguen sobre els condicionants ideològics $i$ les pressions externes que afecten en les decisions que prenen les dones abans, durant i després del seu tractament. Quins són els motius pels quals decideixen reconstruir-se els pits o no fer-ho?

Plantejaments similars sorgeixen explorant l'oncofertilitat. Aquest tractament amplia les opcions de les dones sobre la maternitat $i$ alleuja el malestar que produeix, en algunes, la possibilitat de no poder tenir fills o filles biològiques: "Compassivament, l'oncofertilitat respon a l'angoixa de la infertilitat que experimenten moltes dones" (Roberts, 2016, p. 138). Al mateix temps, pot contribuir a incentivar, encara més, el desig de les dones per ser mares. El debat està servit.

Les polèmiques que genera el biaix androcèntric en la biomedicina també assenyalen les investigacions científiques, que sovint no apliquen perspectiva de gènere. Les autores de $\mathrm{C} i$ catrius (in)visibles denuncien que, entre les prioritats de la biomedicina no es troben les indagacions sobre les causes del càncer de mama, i que aquest buit de coneixement impedeix exigir responsabilitats als poders públics encarregats de desenvolupar les polítiques públiques corresponents. Evitar que les dones s'exposin a condicions mediambientals $i$ laborals que no estimulin la producció d'estrògens podria reduir les seves probabilitats de patir càncer de mama. Per contra, les institucions sanitàries continuen centrades en les proves de cribratge - l'ús de les quals ha estat qüestionat a partir dels resultats d'estudis científics- que es promocionen com una forma de prevenció $i$, fins i tot, de cura del càncer de mama. La insistència en les polèmiques proves de cribratge $i$ les poques investigacions sobre els factors causants de la malaltia que afecta a tantes dones són una mostra més del biaix androcèntric.

El mateix biaix que desatén les diferències de gènere, impedeix que es reconeguin les diferències entre les dones. La classe social afecta a les experiències del càncer. Ignorar les diferències és un obstacle pel bon desenvolupament de les polítiques públiques, la justa distribució de recursos, i el reconeixement dels drets de les dones en funció de les seves con- 
dicions materials i el seu estatus. És una qüestió rellevant, tenint en compte que, tal i com assenyalen les autores de la publicació, les possibilitats de les afectades pel càncer depenen, en gran mesura, de les seves possibilitats econòmiques. Un emparament legal deficient desprotegeix les dones i pot empitjorar els malestars derivats de la dolència.

El tercer apartat està dedicat als relats plurals sobre l'experiència del càncer. Mostren l'existència d'una producció cultural diferent de l'hegemònica. Revelen múltiples formes de viure el càncer, també des de fora dels discursos de la superació que construeixen i difonen les institucions públiques i privades i els mitjans de comunicació. Creen un espai per fer que cada dona pugui narrar les seves experiències amb tota la seva complexitat, perquè puguin articular la seva identitat en trànsit i perquè puguin restituir el seu cos, com elles desitgin, després de la malaltia.

El càncer no és sempre un combat contra un enemic focalitzat al cos. El càncer pot pensarse com una part més de la persona que el pateix. La malaltia i la mort també són part de la vida. Aquestes reflexions, i també moltes altres, apareixen als fragments literaris extrets dels diaris personals d'escriptores i poetesses que durant els anys 80's obriren camí a altres relats amarats de por, llàgrimes, ferides, i pus. Altres artistes plasmaren la vulnerabilitat de les pacients davant del poder mèdic que té el monopoli del coneixement sobre la malaltia. La col-lecció d'aquests relats, compilats a $\mathrm{Ci}$ catrius (in)visibles constitueix un cos nou, un cos que es restitueix a base de destapar sutures. També conformen un cos polític que apel-la la consciència social i exigeix responsabilitats. Un cos nodrit de teorització indispensable de la malaltia que complementa el coneixement parcial de la biomedicina. Un cos que fa visible les cicatrius per testimoniar allò del que no es parla.

\section{Referències}

Coll-Planas, Gerard (2016). El context ideològic de la vivència del càncer de mama. A Ana PorrocheEscudero, Gerard Coll-Planas \& Caterina Riba (Eds.), Cicatrius (in)visibles (pp. 33-44). Vic: Eumo Editorial.

Roberts, Dorothy (2016). El context social de l'oncofertilitat. A Ana Porroche-Escudero, Gerard Coll-Planas \& Caterina Riba (Eds.), Cicatrius (in)visibles (pp. 135-148). Vic: Eumo Editorial.

\section{KeREn MANZANo GonZÁLEZ}

Periodista i analista de gènere. Investigadora del Grup d'Estudis de Gènere: Traducció, Literatura, Història i Comunicació de la Universitat de Vic - Universitat Central de Catalunya

\section{DIRECCIÓN DE CONTACTO}

keren.manzano.gonzalez@gmail.com

\section{FORMATO DE CITACIÓN}

Manzano González, Keren (2016). Ressenya de Porroche-Escudero, Coll-Planas i Riba (Eds.) (2016): Cicatrius (in)visibles. Perspectives feministes sobre el càncer de mama. Quaderns de Psicologia, 18(3), 109-111. http://dx.doi.org/10.5565/rev/qpsicologia. 1373 